\title{
Nitrogen removal in integrated anaerobic-aerobic sequencing batch reactors and constructed wetland system: a field experimental study
}

\author{
Risko Assefa ${ }^{1}$ (1) $\cdot$ Ramani Bai $^{2} \cdot$ Seyoum Leta ${ }^{3} \cdot$ Helmut Kloos $^{4}$
}

Received: 30 August 2018 / Accepted: 24 June 2019 / Published online: 6 July 2019

(c) The Author(s) 2019

\begin{abstract}
A study was conducted to assess the performance of an integrated system consisting of an anaerobic digester (AD), an aerobic sequence batch reactor (ASBR), and three horizontal subsurface flow constructed wetlands (HSSFCWs) vegetated with the perennial grass Phragmites karka for removal of nitrogen in tannery wastewater. Nine grab wastewater samples were collected weekly between September and December 2016 from the influent and effluent at each unit of operation of the plant and analyzed for physicochemical parameters. The AD removed $67 \%$ of oxidized nitrogen $\left(\mathrm{NO}_{X}-\mathrm{N}\right)$; the removal was improved to $76 \%$ in the ASBR with a further aeration period in the HSSFCWs, and the $\mathrm{NO}_{X}-\mathrm{N}$ removal efficiency improved progressively to $96 \%$. The removal efficiency for nitrate $\left(\mathrm{NO}_{3}-\mathrm{N}\right)$ was $82 \%$ and for nitrite $\left(\mathrm{NO}_{2}-\mathrm{N}\right) 88 \%$; for ammonium $\left(\mathrm{NH}_{4}-\mathrm{N}\right)$ removal efficiency was $77 \%$ higher in the HSSFCWs compared to the AD and the ASBR. Despite the considerable percentage of $\mathrm{NO}_{3}-\mathrm{N}$ removed, in the effluent was above the country's permissible limit $(39.3 \mathrm{mg} / \mathrm{l})$. The high concentration might be due to a weaker denitrification process in HSSFCWs caused by lack of carbon and external organic sources in the wastewater sufficient to carry out the process. The results suggest that the addition of supplementing carbon sources (methanol, sugars, or volatile fatty acids) to the effluent would achieve better performance. Based on these findings, the application of combined anaerobic/aerobic system connected with constructed wetlands process allows the achievement of higher efficiency in removing nitrogen compared to the use of an anaerobic, aerobic, or constructed wetland system along.
\end{abstract}

Keywords Anaerobic-aerobic treatment $\cdot$ Constructed wetland $\cdot$ Nitrogen removal $\cdot$ Tannery wastewater $\cdot$ Modjo Tannery $\cdot$ Ethiopia

\section{Introduction}

In the face of the emerging concern for environmental preservation and governmental regulations that are becoming more stringent, the development of innovative, sustainable, environmentally friendly, and low-cost processes for efficient treatment of tannery wastewater has gained the interest

Risko Assefa

riskoassea@gmail.com; risko.assefa@aau.edu.et

1 Ethiopian Institute of Water Resources, Addis Ababa University, P.O. Box 150461, Addis Ababa, Ethiopia

2 School of Civil Engineering, Linton University College, Bandar University Technology Legenda (BUTL), Mantin, Negeri Sembilan, Malaysia

3 Center for Environmental Sciences, Addis Ababa University, Addis Ababa, Ethiopia

4 Department of Epidemiology and Biostatistics, University of California, San Francisco, CA, USA of researchers in clean technologies. Tannery effluent contains large amounts of ammonia nitrogen $\left(\mathrm{NH}_{3}-\mathrm{N}\right)$ and total nitrogen (TN) due to the addition of ammonium salts during deliming and batting and the removal of non-collagenous proteins from raw hide in beam house processes (UNIDO 2000, 2011).

The discharge of high nitrogen concentrations into receiving waters without proper treatment can lead to an imbalance in the natural ecological system that boosts eutrophication; depletion of dissolved oxygen in surface waters, killing fish and creating septic conditions; and odor problems. It also causes toxicity and increased risks to human health, as high $\mathrm{NO}_{3}{ }^{-}-\mathrm{N}$ concentrations in groundwater cause methemoglobinemia in infants (Gerardi 2002; Seyoum et al. 2003; Paredes et al. 2007; de Sousa et al. 2008; Durai and Rajasimman 2011).

The operation of tanneries in Ethiopia is causing severe environmental degradation due to the disposal of untreated effluent into water bodies and on land. The discharge of 
highly toxic wastewater from tanneries in and near Modjo Town into the Modjo River poses risks for irrigation, recreation, and human and livestock consumption (Seyoum et al. 2003).

Biological tannery wastewater is primarily treated with single-treatment methods (de Sousa et al. 2008; Durai et al. 2010; Calheiros et al. 2012; Alemu and Leta 2015). Each treatment system has its merits and demerits. For instance, anaerobic systems use less energy and produce less sludge but require a longer detention period and emit unpleasant odors (Goswami and Mazumder 2014). In aerobic systems, decomposition is more rapid than in anaerobic systems and unpleasant odors are avoided, but the systems produce more sludge (Vanatta and Slingsby 2003; Durai and Rajasimman 2011). On the other hand, constructed wetlands are low cost, environmental friendly, and easily operated biological systems; however, they can be used only as a tertiary treatment system for tannery wastewater due to high chemical toxicity of the wastewater (Lee et al. 2009; Redmond 2012). Several studies indicate that using anaerobic-aerobic sequencing batch reactors in a combined system to treat tannery wastewater can give better results than the individual treatment processes (Lefebvre et al. 2006; Faouzi et al. 2013; Ganesh et al. 2014; Wu et al. 2014).

Recent studies (Desta et al. 2014; Alemu et al. 2016) extended the idea of an integrated treatment system with the inclusion of constructed wetlands. These studies noted that the overall removal performance, biogas generation rate, and microbial communities residing in the system make it efficient for the treatment of tannery wastewater. However, the system performance in removing nitrogen species was inadequately recognized and documented. Therefore, this study aimed to determine the nitrogen removal efficiency of a system integrating an anaerobic digester, an aerobic sequencing batch reactor, and constructed wetlands as well as the efficiencies of the individual unit operations in order to establish operating strategies capable of achieving high levels of nitrogen removal in tannery wastewater.

\section{Materials and methods}

\section{The study site}

The study was conducted at a pilot-scale biological wastewater treatment plant (WWTP) built on the premises of the Modjo Tannery Share Company by the Center of Environmental Science of Addis Ababa University in collaboration with AKUT Burkard and Partner (Germany). The Modjo Tannery Share Company is located near Modjo Town, $75 \mathrm{~km}$ southeast of Addis Ababa at an altitude of $1825 \mathrm{~m}$ (Fig. 1). The tannery has a capacity of processing 1,656,000 sheep and 844,000 goat skins and 93,075 cattle hides per annum and generates $3500-5500 \mathrm{~m}^{3}$ of wastewater per day.

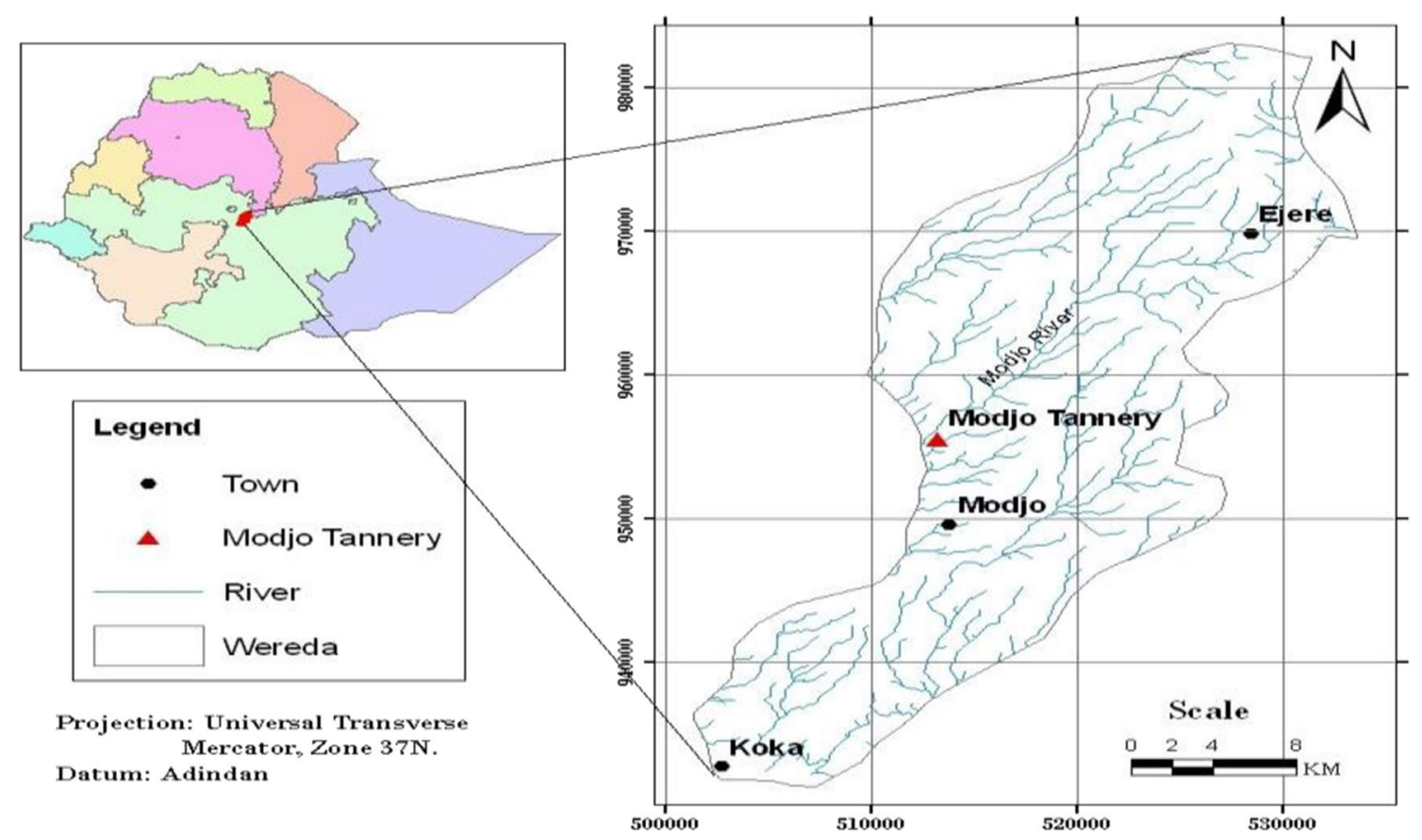

Fig. 1 Location of the study site within the Modjo River basin 


\section{Integrated wastewater treatment plant}

The integrated WWTP starts with tannery effluent $\left(25 \mathrm{~m}^{3}\right)$ fed into a primary screening tank followed by grit removal, to eliminate coarse organic matter and suspended solids from the raw wastewater. Then, the effluent is transferred into two anaerobic reactors of the same size, with hydraulic retention time (HRT) of $24 \mathrm{~h}$ and is subsequently channeled to the SBR fitted with an aeration pump and is mixed for $12 \mathrm{~h}$. The effluent from the aerobic reactor is then fed into a sedimentation tank for sludge settling and is then continuously fed into three horizontal subsurface flow constructed wetlands vegetated with the perennial grass Phragmites karka at a loading rate of $120 \mathrm{~kg} / \mathrm{BOD}_{5} / \mathrm{ha} /$ day. A schematic illustration of the wastewater treatment plant and sampling points and a brief description of each unit's operations design are presented in Fig. 2, Tables 1 and 2.

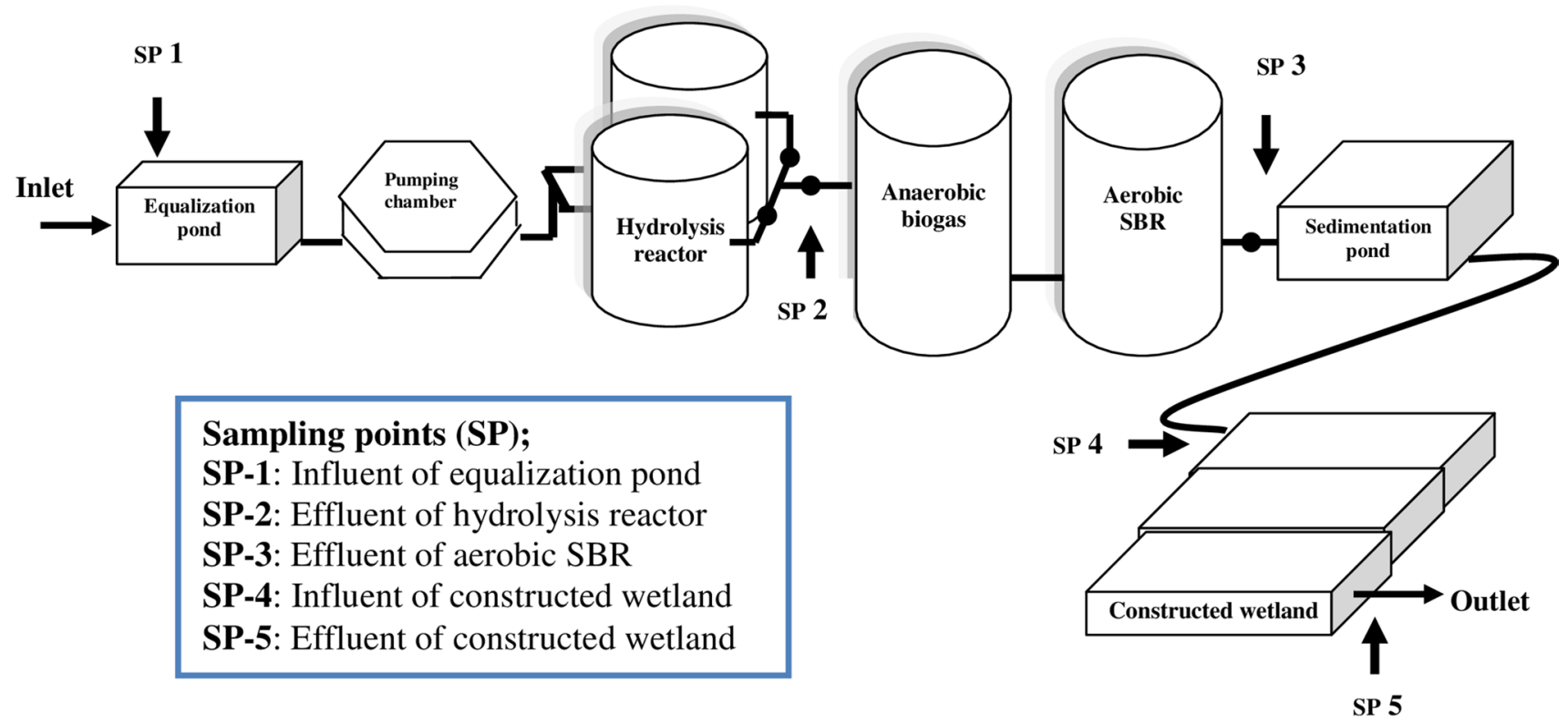

Fig. 2 Schematic of the integrated wastewater treatment plant and sampling points

Table 1 Design of hydrolysis reactor, biogas digester, aerobic SBR, and sedimentation tank

\begin{tabular}{|c|c|c|c|c|}
\hline & Diameter (m) & & Height (m) & Volume $\left(\mathrm{m}^{3}\right)$ \\
\hline Hydrolysis reactor & 3.6 & & 3.3 & 25 \\
\hline Biogas digester & 6 & & 4 & 113 \\
\hline \multirow[t]{2}{*}{ Aerobic SBR } & 12.3 & & 6 & 60 \\
\hline & Length (m) & Width (m) & Height (m) & Volume $\left(\mathrm{m}^{3}\right)$ \\
\hline Sedimentation tank & 10 & 4 & 2.5 & 50 \\
\hline
\end{tabular}

SBR sequencing batch reactor

Table 2 Design of three horizontal subsurface flow constructed wetlands (CWs)

\begin{tabular}{lllllll}
\hline Three horizontal subsurface constructed wetlands & Length $(\mathrm{m})$ & Width $(\mathrm{m})$ & Depth $(\mathrm{m})$ & Volume $\left(\mathrm{m}^{3}\right)$ & Flow rate $\left(\mathrm{m}^{3} / \mathrm{day}\right)$ & HRT $($ days $)$ \\
\hline & 30 & 5 & 0.6 & 70.9 & 23.6 & 3 \\
\hline
\end{tabular}

CWs constructed wetlands, HRT hydraulic retention time 


\section{Sample collection}

Grab samples were collected on a weekly basis from five sampling points: influent of equalization pond (SP-1), effluent of hydrolysis reactor (SP-2), effluent of aerobic SBR (SP-3), influent of constructed wetlands (SP-4), and effluent of constructed wetlands (SP-5). Each sampling point was sampled 9 times from September to November 2015. Plastic bottles $(500 \mathrm{~mL})$ were used to collect the wastewater samples for physicochemical analysis. The collected samples were labeled and transported to the Addis Ababa University (AAU) Environmental Science Research Laboratory in an ice box in accordance with standard methods for the examination of water and wastewater procedures (APHA, AWWA, and WEF 1998).

\section{Physicochemical analyses}

Temperature, $\mathrm{pH}$, electrical conductivity (EC), and total dissolved solids (TDS) were measured in situ using a combined US digital handheld LCD $\mathrm{pH} / \mathrm{T}{ }^{\circ} \mathrm{C} / \mathrm{TDS} / \mathrm{EC}$ meter. Biological oxygen demand (BOD) was measured by APHA $5210 \mathrm{~B}$ in a 5-day BOD test. Turbidity was measured by APHA 2130 B (nephelometric method) (APHA, AWWA, and WEF 1998). The physicochemical analyses of total suspended solids, ammonium (Nessler method), nitrate (cadmium reduction method using NitraVer ${ }^{\circledR} 5$ nitrate reagent), nitrite (ferrous sulfate method via Nitri Ver ${ }^{\circledR}$ 2 nitrite reagent), total nitrogen (persulfate digestion), chemical oxygen demand (potassium dichromate reactor digestion), phosphorus reactive (ascorbic acid method) using Phos Ver 3 reagent phosphate, sulfate (turbidimetric method) by SulfaVer 4 reagent, and sulfide (methylene blue method) were measured photometrically using $\mathrm{HACH}$ DR/2400 spectrophotometer (Hach 2004) according to the HACH DR/2400 (2004) procedures manual (Hach 2004). Reagent blanks and duplicate samples were tested in parallel for each analysis.

\section{Data analysis}

The pollutant removal rates were calculated as percentages according to the following equation (APHA, AWWA, and WEF 1998):

$R=\left(\frac{C_{\mathrm{i}}-C_{\mathrm{f}}}{C_{\mathrm{i}}}\right) \times 100$

where $R$ is the removal rate (\%) and $C_{\mathrm{i}}$ and $C_{\mathrm{f}}$ are the initial and final concentrations of pollutants. Statistical analysis was performed using SPSS software version 24.0. One-way
ANOVA (analysis of variance) was used to compare the performance of each unit's operation (AD, SBR, CW) for the removal of major nutrient and organic matter in order to determine significant differences $(p<0.05)$ in removal efficiency. A linear regression line was plotted to determine correlation between parameters.

\section{Results and discussion}

\section{Characterization of wastewater}

The characteristics of the wastewater at different treatment stages of the pilot plant are presented in detail in Table 3 .

These findings show that the treated effluent of the constructed wetlands is within the permissible limits of Ethiopian environmental regulations for tannery effluent except for nitrate $(39.3 \mathrm{mg} / \mathrm{l})(\mathrm{EEPA} 2003)$. The high concentration of nitrate in the effluent could be due to the low denitrification rate in the HSSFCW. In denitrification, nitrate or nitrite is used as an electron acceptor and organic carbon as an electron donor (Kadlec and Wallace 2009). In constructed wetlands, organic carbon is needed as an electron donor for nitrate reduction, which provides an energy source for denitrification (Redmond 2012). Most wastewater does not have enough biodegradable carbon and external organic sources to support denitrification. Studies have shown that the denitrification rate in organic carbon-restricted wastewater can be improved with supplemental carbon. A supplemental, exogenous source of carbon (e.g., methanol, sugars, or volatile fatty acids) can be added to the effluent to achieve better treatment (Lee et al. 2009; Redmond 2012).

Constructed wetland plants enhance treatment efficiency by providing a favorable environment for the development of microbial populations through oxygenating the system. Artificial aeration of the HSSFCW can achieve higher nitrate removal by providing sufficient DO for nitrification, and a favorable anoxic environment can be created for denitrification (Fan et al. 2013).

The average $\mathrm{BOD}_{5} / \mathrm{COD}$ ratio for the influent was 0.15 . The typical $\mathrm{BOD}_{5} / \mathrm{COD}$ ratio of tannery wastewater is 0.4 , although it can range from 0.3 to 0.5 in untreated effluent (UNIDO 2000). According to Tehobanoglous et al. (2003), $\mathrm{BOD}_{5} / \mathrm{COD}$ ratios below 0.5 indicate a possibility that chemical substances that have low biodegradability will slacken or delay the biological process and easily biodegradable organic matter $\left(\mathrm{BOD}_{5}\right)$ will be consumed. Because of acclimation of microorganisms in the biological WWTP, the effluent showed a higher $\mathrm{BOD}_{5} /$ COD ratio of 0.7 . This shows that about $70 \%$ portion of organic matter in the wastewater is biodegradable in nature (Tehobanoglous et al. 2003). Tannery wastewater has a high content of organic matter that varies according to the 
Table 3 Characteristics of the wastewater at different stages of the WWTP

\begin{tabular}{|c|c|c|c|c|c|c|}
\hline Parameter & $\begin{array}{l}\text { Influent of } \\
\text { Equalization Pond } \\
\text { (SP-1) }\end{array}$ & $\begin{array}{l}\text { Effluent of AD } \\
\text { (SP-2) }\end{array}$ & $\begin{array}{l}\text { Effluent of ASBR } \\
\text { (SP-3) }\end{array}$ & $\begin{array}{l}\text { Influent of CW(SP- } \\
\text { 4) }\end{array}$ & $\begin{array}{l}\text { Effluent of CW } \\
\text { (SP-5) }\end{array}$ & EEPA (2003) \\
\hline Temperature $\left({ }^{\circ} \mathrm{C}\right)$ & $24.9 \pm 3.5$ & $23.6 \pm 1.5$ & $25.8 \pm 2.9$ & $25.8 \pm 2.9$ & $25.3 \pm 2.8$ & 40 \\
\hline $\mathrm{pH}$ & $8.0 \pm 1.6$ & $6.9 \pm 1.6$ & $6.8 \pm 1.7$ & $6.1 \pm 1.7$ & $6.3 \pm 1.5$ & $6-9$ \\
\hline $\mathrm{EC}(\mu \mathrm{s} / \mathrm{cm})$ & $15,594.4 \pm 817.2$ & $9257.7 \pm 918.0$ & $2861.1 \pm 96.0$ & $2456.1 \pm 62.0$ & $455.0 \pm 118.9$ & 8500 \\
\hline TSS (mg/l) & $2011.8 \pm 306.2$ & $670.7 \pm 410.4$ & $242.7 \pm 127.5$ & $331 \pm 197.1$ & $21.0 \pm 8.4$ & 50 \\
\hline Turbidity (NTU) & $630.4 \pm 138.4$ & $282.6 \pm 103.8$ & $76.2 \pm 17.3$ & $99 \pm 4.0$ & $15.2 \pm 2.8$ & - \\
\hline TDS (mg/l) & $10,170.4 \pm 499.5$ & $4406.8 \pm 620.1$ & $991.9 \pm 495.2$ & $844.9 \pm 128.2$ & $340.3 \pm 114.0$ & - \\
\hline $\mathrm{NH}_{4}-\mathrm{N}(\mathrm{mg} / \mathrm{l})$ & $130.8 \pm 46.8$ & $60.4 \pm 5.1$ & $56.2 \pm 8.4$ & $86.2 \pm 6.5$ & $19.5 \pm 8.4$ & 30 \\
\hline $\mathrm{NO}_{3}-\mathrm{N}(\mathrm{mg} / \mathrm{l})$ & $591.6 \pm 160.8$ & $301.7 \pm 84.6$ & $169.9 \pm 59.9$ & $214.3 \pm 10.6$ & $39.3 \pm 8.6$ & 10 \\
\hline $\mathrm{NO}_{2}-\mathrm{N}(\mathrm{mg} / \mathrm{l})$ & $1684.4 \pm 263.2$ & $811.1 \pm 261.9$ & $325.8 \pm 50.0$ & $918.7 \pm 13.5$ & $112.3 \pm 36.9$ & - \\
\hline $\mathrm{TN}(\mathrm{mg} / \mathrm{l})$ & $664.2 \pm 127.2$ & $254.3 \pm 70.5$ & $65.7 \pm 19.6$ & $173.7 \pm 59.5$ & $48.1 \pm 13.5$ & 60 \\
\hline $\mathrm{COD}(\mathrm{mg} / \mathrm{l})$ & $6249.7 \pm 1573.9$ & $2311.1 \pm 849.2$ & $507.8 \pm 275.6$ & $1134.4 \pm 155.6$ & $191.8 \pm 74.9$ & 500 \\
\hline $\mathrm{BOD}_{5}(\mathrm{mg} / \mathrm{l})$ & $864.4 \pm 198.0$ & $628.9 \pm 172.9$ & $230.7 \pm 92.4$ & $759.9 \pm 238.4$ & $72.1 \pm 17.4$ & 200 \\
\hline $\mathrm{SO}_{4}^{2-}(\mathrm{mg} / \mathrm{l})$ & $523.2 \pm 97.7$ & $266.0 \pm 58.9$ & $147.0 \pm 10.5$ & $219.2 \pm 54.9$ & $163.4 \pm 23.5$ & - \\
\hline $\mathrm{S}^{2-}(\mathrm{mg} / \mathrm{l})$ & $215.6 \pm 74.1$ & $120.0 \pm 90.0$ & $80.8 \pm 11.2$ & $9.2 \pm 1.1$ & $4.5 \pm 1.4$ & - \\
\hline $\mathrm{PO}_{4}{ }^{3-}(\mathrm{mg} / \mathrm{l})$ & $18 \pm 3.4$ & $9 \pm 1.6$ & $23.8 \pm 6.3$ & $28.6 \pm 8.2$ & $10.7 \pm 1.8$ & - \\
\hline
\end{tabular}

Each value of the parameter described as mean value \pm SD

$T N$ total nitrogen, $E C$ electrical conductivity, $T S S$ total suspended solids, $T D S$ total dissolved solids, $\mathrm{NH}_{4}-\mathrm{N}_{\text {ammonium nitrogen, }} \mathrm{NO}_{3}-\mathrm{N}$ nitrate nitrogen, $\mathrm{NO}_{2}-\mathrm{N}$ nitrite nitrogen, $\mathrm{COD}$ chemical oxygen demand, $\mathrm{BOD}$ biochemical oxygen demand, $\mathrm{SO}_{4}^{2-}$ sulfate, $\mathrm{S}^{2-}$ sulfide, $P \mathrm{O}_{4}^{3-}$ phosphate, $S P$ sampling point, EEPA Ethiopian environmental protection authority

Fig. 3 Correlation between $\mathrm{BOD}_{5}$ and $\mathrm{COD}$ in the influent and effluent of the pilot plant
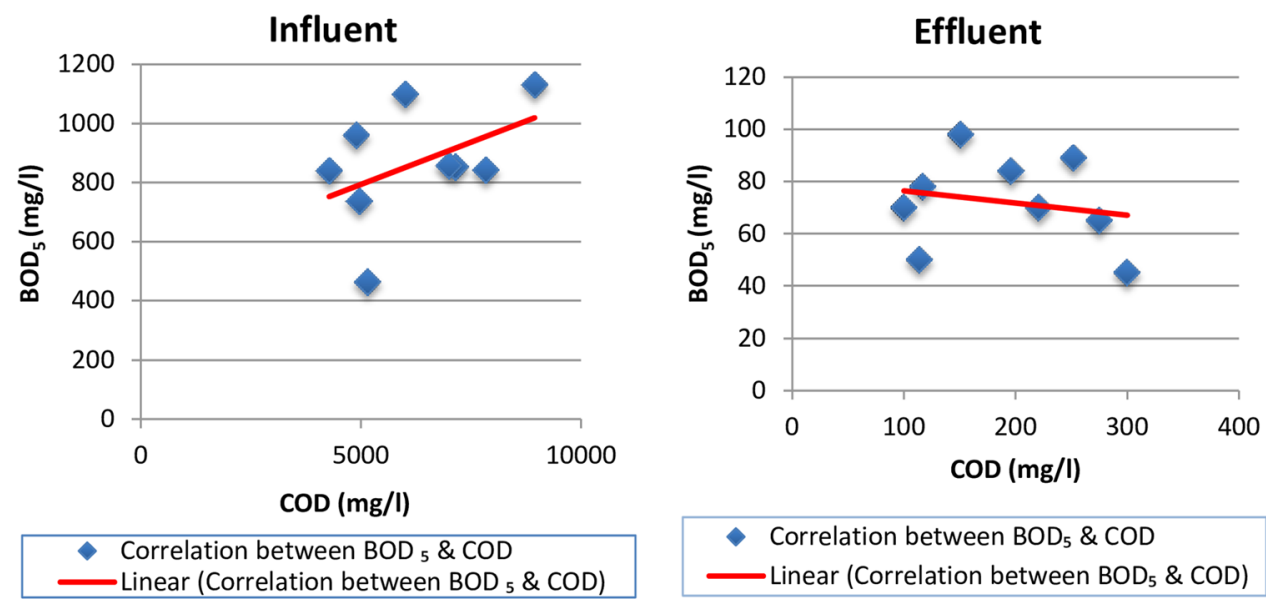

- Correlation between $\mathrm{BOD}_{5}$ \& COD - Linear (Correlation between $\mathrm{BOD}_{5}$ \& COD) usage of various chemicals with different biodegradation characteristics. The liming and unhairing process generates organic matter with high biodegradability, while the organic matter generated from the tanning process (such as chrome $3^{+}$) has low biodegradability (UNIDO 2000).

The correlation between $\mathrm{BOD}_{5}$ and COD and the implication for nitrogen removal are shown in Fig. 3. The slope of the regression line has a value of 0.057 , which indicates a moderate positive correlation between $\mathrm{BOD}_{5}$ and COD in the influent; a weak negative correlation between $\mathrm{BOD}_{5}$ and $\mathrm{COD}$ in the effluent was observed, with a slope of -0.046 . This relationship is influenced by the chemicals used in the different leather making processes and their rates of biodegradability (UNIDO 2000). Tannery wastewater contains broader and more easily biodegradable organic matter (which can be from an internal carbon source) that can maintain more denitrifying consortia to be active in the system (Seyoum et al. 2004b).

The overall removal efficiencies exhibited by the integrated system in different treatment stages of the pilot plant are presented in Fig. 4. 


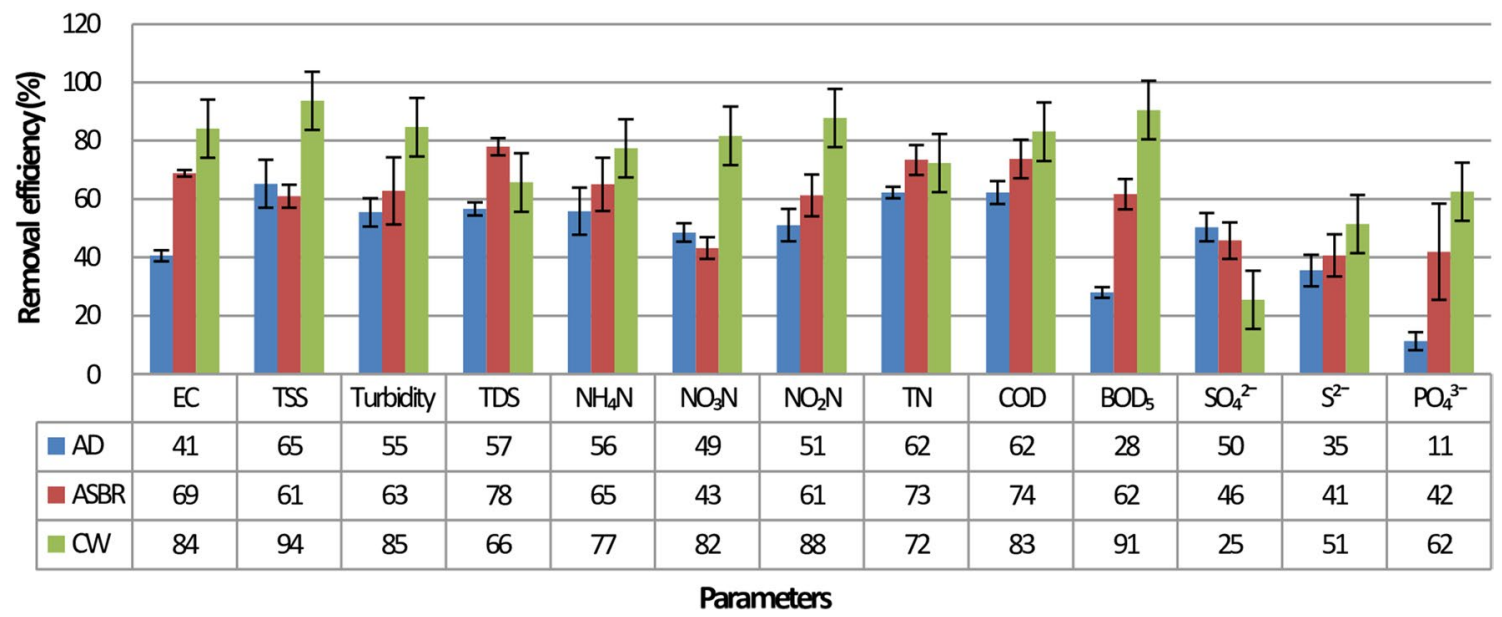

Fig. 4 Performance evaluation of each unit operation (AD, ASBR, and CW)

The optimum $\mathrm{pH}$ average in the effluent of $\mathrm{AD}$ was 6.9, whereas for ASBR it was 6.8 and for CW 6.3 (Table 3). The unit operations had an effective $\mathrm{pH}$ range of 6-9 for the occurrence of denitrification and nitrification (UNIDO 2011). Studies indicate that such reactors favor the development of the nitrifying bacteria growing rapidly in the $\mathrm{pH}$ range of 6.5-8.6 (Gerardi 2002; Seyoum et al. 2003; Tehobanoglous et al. 2003) and denitrifying bacteria in the $\mathrm{pH}$ range 7-8.5 (Barnes and Bliss 1983; Kadlec and Wallace 2009). In the overall WWTP and in each unit operation, the temperature of the wastewater ranged from 21 to $29^{\circ} \mathrm{C}$. Temperature affects the metabolic and growth rates of the organisms responsible for the biological processes. The optimal temperature range for nitrifying bacteria is $5-30{ }^{\circ} \mathrm{C}$ and for denitrifying bacteria $5-45^{\circ} \mathrm{C}$ (Gerardi 2002; Ganesh et al. 2014), indicating that the integrated biological system in the current study is suitable for nitrification and denitrification for bacteria growth.

The average removal efficiencies of $\mathrm{AD}, \mathrm{ASBR}$, and $\mathrm{CW}$ were $65 \%, 61 \%$, and $94 \%$, respectively, for TSS; $55 \%, 63 \%$, and $85 \%$ for turbidity; and 57\%, 78\%, 66\% for TDS (Fig. 4). The removal efficiency of TSS and turbidity in the CW was significantly higher than in the other two reactors $(p<0.05)$. The removal efficiency of TDS was significantly higher (78\%) in aerobic SBR than in the two other unit operations $(p<0.05)$. These higher efficiencies could be due to the prior process of anaerobic digestion that forms methane (methanization) and the denitrification process (Kongjao et al. 2008).

$\mathrm{BOD}_{5}$ and COD of the effluents of AD were $628.9 \mathrm{mg} / \mathrm{l}$ and $2311.1 \mathrm{mg} / \mathrm{l}$, with an average removal efficiency of $28 \%$ for $\mathrm{BOD}_{5}$ and $62 \%$ for COD (Fig. 5). Relatively low effectiveness could be the result of the high concentration of slowly degradable or non-biodegradable organics in the influent. This can be confirmed by low $\mathrm{BOD}_{5} / \mathrm{COD}$ $(0.15)$ in raw wastewater. For the effluent in $\mathrm{ASBR}, \mathrm{BOD}_{5}$ concentrations of $230.7 \mathrm{mg} / \mathrm{l}$ and COD $507.8 \mathrm{mg} / \mathrm{l}$ with average removal efficiency of $74 \%$ for $\mathrm{BOD}_{5}$ and $62 \%$ for $\mathrm{COD}$ were recorded. The CW's effluent $\mathrm{BOD}_{5}$ concentration of $72.1 \mathrm{mg} / \mathrm{l}$ had $91 \%$ removal efficiency, and its COD concentration of $191.8 \mathrm{mg} / \mathrm{l}$ achieved $83 \%$ average removal efficiency (Fig. 5). The constructed wetlands showed significantly higher removal efficiency for $\mathrm{BOD}_{5}$ and $\mathrm{COD}$ from the other two unit operations $(p<0.05)$.

The removal efficiency of an advanced integrated wastewater pond system for tannery wastewater treatment was in a high range of $90-97 \%$ for COD and $92-99 \%$ for $\mathrm{BOD}_{5}$ (Tadesse et al. 2004). Seyoum et al. (2004a) also used a predenitrification/nitrification system at a pilot plant level to treat composite tannery wastewater and obtained $95-98 \%$ removal efficiency of COD and $96-98 \%$ for $\mathrm{BOD}_{5}$.

Lefebvre et al. (2006) showed that the aerobic SBR reactor alone removed $95 \%$ of the COD and up-flow anaerobic sludge blanket (UASB) removed only $77 \%$ of COD. The combination of anaerobic and aerobic processes, on the other hand, achieved 96\% COD removal. Reemtsma and Jekel (1997) observed that combined anaerobic/aerobic removal efficiency (94\% abatement in COD) was significantly greater than with the anaerobic filter alone (60\%).

The present study revealed that the average concentration of sulfide $\left(\mathrm{S}^{2-}\right)$ in the effluent of AD was $120 \mathrm{mg} / \mathrm{l}$, while the effluent of ASBR $(80.8 \mathrm{mg} / \mathrm{l})$ and the constructed wetlands was $4.5 \mathrm{mg} / \mathrm{l}$ (Table 3). The sulfide removal in AD was $35 \%$, in ASBR $41 \%$ and $51 \%$ in CW (Fig. 4). The constructed wetlands showed higher $\mathrm{S}^{2-}$ removal efficiency with no significant difference $(p>0.05)$ from the other unit operations. Lower removal efficiency rate (less than 50\%) of $\mathrm{S}^{2-}$ exhibited in the unit operations might be due to the $\mathrm{pH}$ of the wastewater; under alkaline conditions, $\mathrm{S}^{2-}$ remains largely in solution, as shown in Table 3 . Average $\mathrm{pH}$ values of the effluents of $\mathrm{AD}, \mathrm{ASBR}$, and $\mathrm{CW}$ were $6.9,6.8$, and 


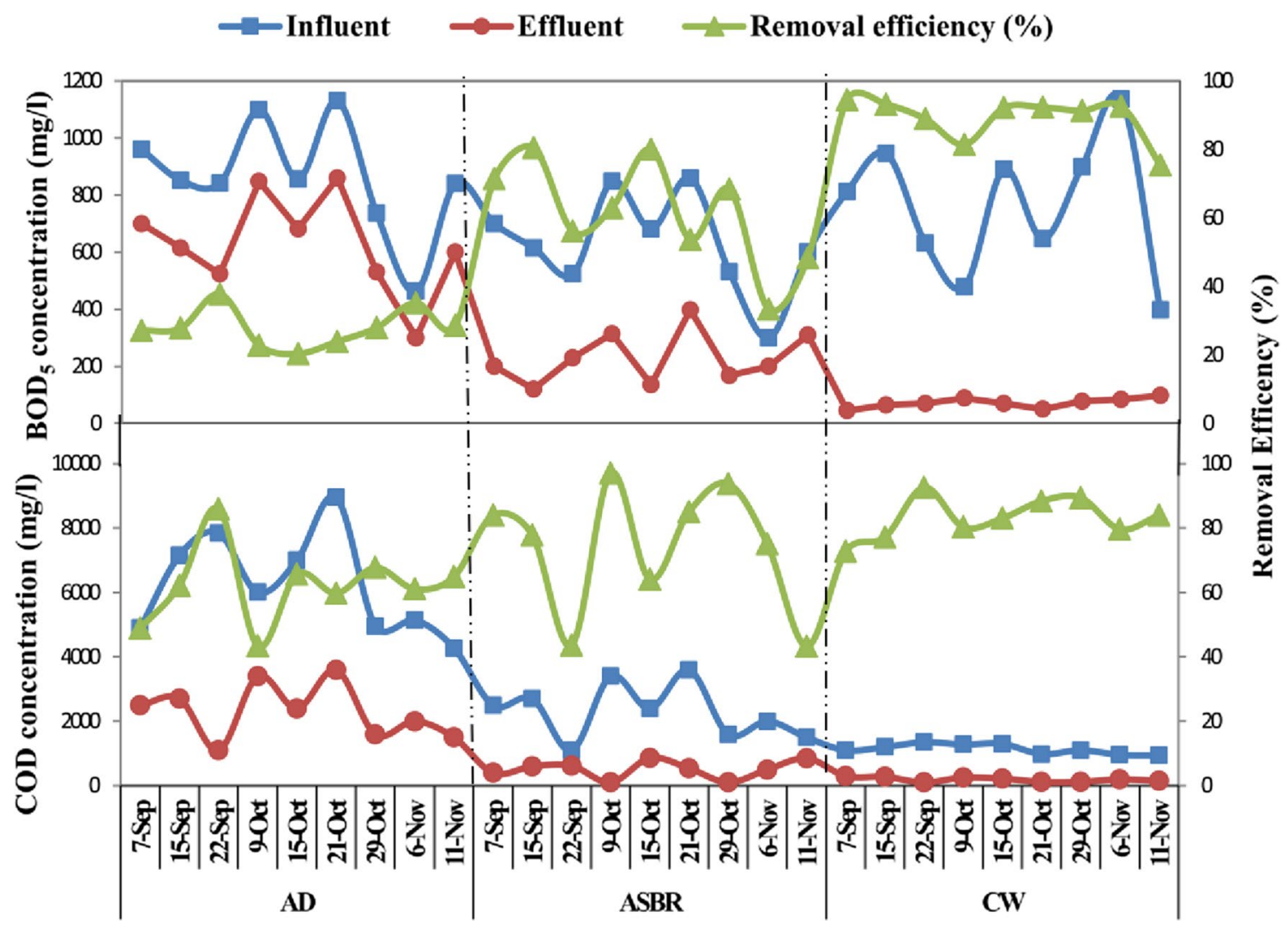

Fig. 5 Variations in removal efficiencies of $\mathrm{BOD}_{5}$ and $\mathrm{COD}$ with different concentration in the influent and effluent of each unit operation during the sampling periods

6.3 , respectively. When the $\mathrm{pH}$ of the effluent drops below 9.5, hydrogen sulfide evolves from the effluent: the lower the $\mathrm{pH}$, the higher the rate of evolution (Gerardi 2002; Tehobanoglous et al. 2003).

Sulfate $\left(\mathrm{SO}_{4}{ }^{2-}\right)$ was broken down into hydrogen sulfide by anaerobic bacteria in the $\mathrm{AD}$, showing $50 \%$ removal efficiency, whereas the ASBR showed a lower removal efficiency of $46 \%$ and CW exhibited the lowest removal efficiency (25\%) (Fig. 4). The concentration of sulfate in the final effluent may rise in the ASBR by aeration since the oxidation process creates sodium sulfate during removal of sulfide components. The activities of nitrate-reduced sulfate oxidizing (NR-SO) bacteria suppress sulfate reduction and contribute to the removal of sulfide originally present in the influent wastewater (Seyoum et al. 2004a). The effluent's $\mathrm{PO}_{4}{ }^{3-}$ was $9 \mathrm{mg} / \mathrm{l}$ in $\mathrm{AD}, 23.8 \mathrm{mg} / \mathrm{l}$ in ASBR, and $10.7 \mathrm{mg} / \mathrm{l}$ in $\mathrm{CWs}$, with average removal efficiencies of $11 \%, 42 \%$, and $62 \%$, respectively. Although the constructed wetlands showed higher removal efficiency, the difference is not statistically significant at $p<0.05$.

\section{Efficiency of nitrogen removal}

The biological processes of nitrogen removal in wastewater are nitrification and denitrification. Denitrification is the reduction in nitrate to nitrogen gas by heterotrophic bacteria using nitrate as an electron acceptor and organic matter as carbon sources under anoxic conditions. Nitrification is the biological oxidation of ammonia to nitrite/nitrate by two specialized groups of autotrophic bacteria under aerobic conditions (Seyoum et al. 2004a). Use of nitrification and denitrification in treating wastewater with high levels of ammonium requires high energy input in order to supply oxygen during nitrification and high alkalinity levels, decreasing the $\mathrm{pH}$ and affecting system stability. In addition, due to the presence of organic carbon and high ammonium levels, the nitrogen removal through denitrification is insufficient. Pre-denitrification prior to nitrification, using organic carbon in raw wastewater efficiently for nitrogen removal, can decrease the production of sludge and lower operating cost. Pre-denitrification is the most efficient strategy for simultaneous removal of nitrogen and organic matter from tannery wastewater (Seyoum et al. 2004a; Ganesh et al. 2014; Wu et al. 2014; Pire-Sierra et al. 2016). 
The anaerobic digester and aerobic reactor components of the integrated system remove nitrogen through the pre-denitrification process. This process can be used for the treatment of tannery wastewater laden with toxic substances containing high concentrations of degradable organic carbon, nitrogen, and ammonia. This process allows the optimal use of the incoming wastewater as carbon sources for denitrification, protects sensitive nitrifying organisms from toxic shocks, and helps to achieve a high degree of nitrification (Seyoum et al. 2003). Similarly, HSSFCWs remove nitrogen from wastewater through plant uptake, storage (assimilation or sediment adsorption and accretion) in the system, and removal through nitrification-denitrification and ammonia volatilization (Kadlec and Wallace 2009).

The maximum removal efficiencies of $\mathrm{AD}, \mathrm{ASBR}$, and CW were $69 \%, 90 \%$, and $83 \%$ for total nitrogen (TN) and $100 \%, 96 \%$, and $94 \%$ for ammonium nitrogen $\left(\mathrm{NH}_{4}-\mathrm{N}\right)$, respectively (Fig. 6). These results suggest that the operation units in the integrated treatment plant are more efficient than the stand-alone systems in removing ammonium nitrogen from wastewater. Plants and microorganisms consume nitrogen in the form of ammonium ions from organic matter (Paredes et al. 2007).

Suspended denitrifying bacteria reduced nitrite and nitrate to nitrogen gas using tannery wastewater as carbon sources. Denitrification and nitrification, therefore, occurred simultaneously in the system in anaerobic-aerobic and constructed wetland columns, respectively. Nitrification activity in the CW was high; the Phragmites karka wetlands showed adequate nitrification. The results agree with those of Seyoum et al. (2004a), who reported removal efficiency of $82-95 \%$ for total nitrogen and $45-95 \%$ for ammonium nitrogen.

The concentrations of the nitrogen species present in the effluents and the total nitrogen (TN) removal efficiency in all the phases are presented in Fig. 7. In the AD system, about $62 \%$ of TN was removed, leaving average concentrations of $301.7 \mathrm{mg} / \mathrm{l}\left(\mathrm{NO}_{3}-\mathrm{N}\right), 811.1 \mathrm{mg} / \mathrm{l}\left(\mathrm{NO}_{2}-\mathrm{N}\right)$, and $60 \mathrm{mg} / \mathrm{l}$ $\left(\mathrm{NH}_{4}-\mathrm{N}\right)$ in the effluent. In the aeration reactor, the TN

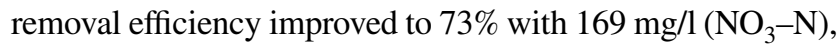
$325 \mathrm{mg} / \mathrm{l}\left(\mathrm{NO}_{2}-\mathrm{N}\right)$, and $56.2 \mathrm{mg} / \mathrm{l}\left(\mathrm{NH}_{4}-\mathrm{N}\right)$ in the effluent. Apparently, in the constructed wetlands the $\mathrm{TN}$ removal efficiency did not improve; only $72 \%$ was exhibited, with
Fig. 6 Changes in the concentration of TN and different forms of nitrogen in each unit operation

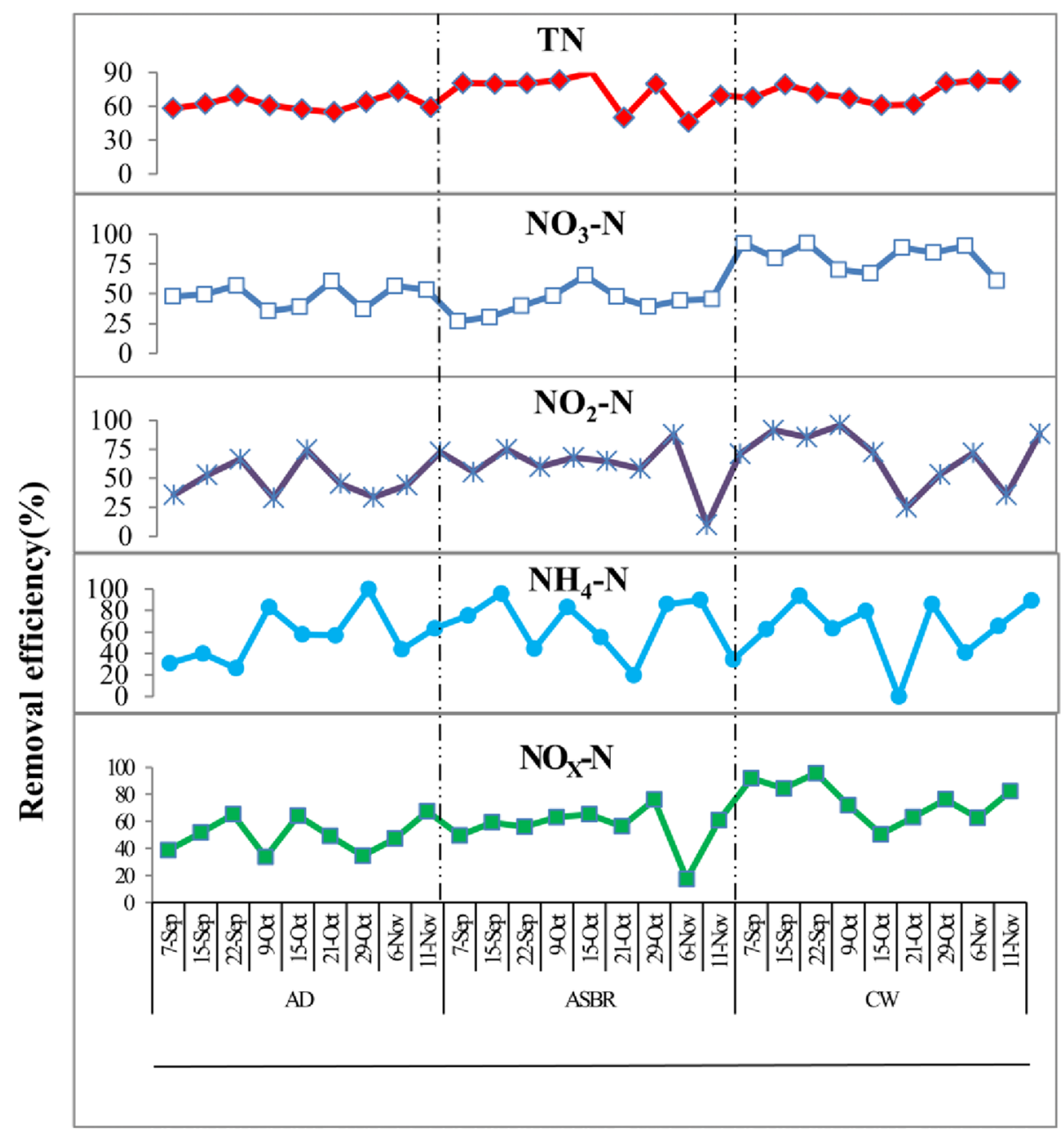




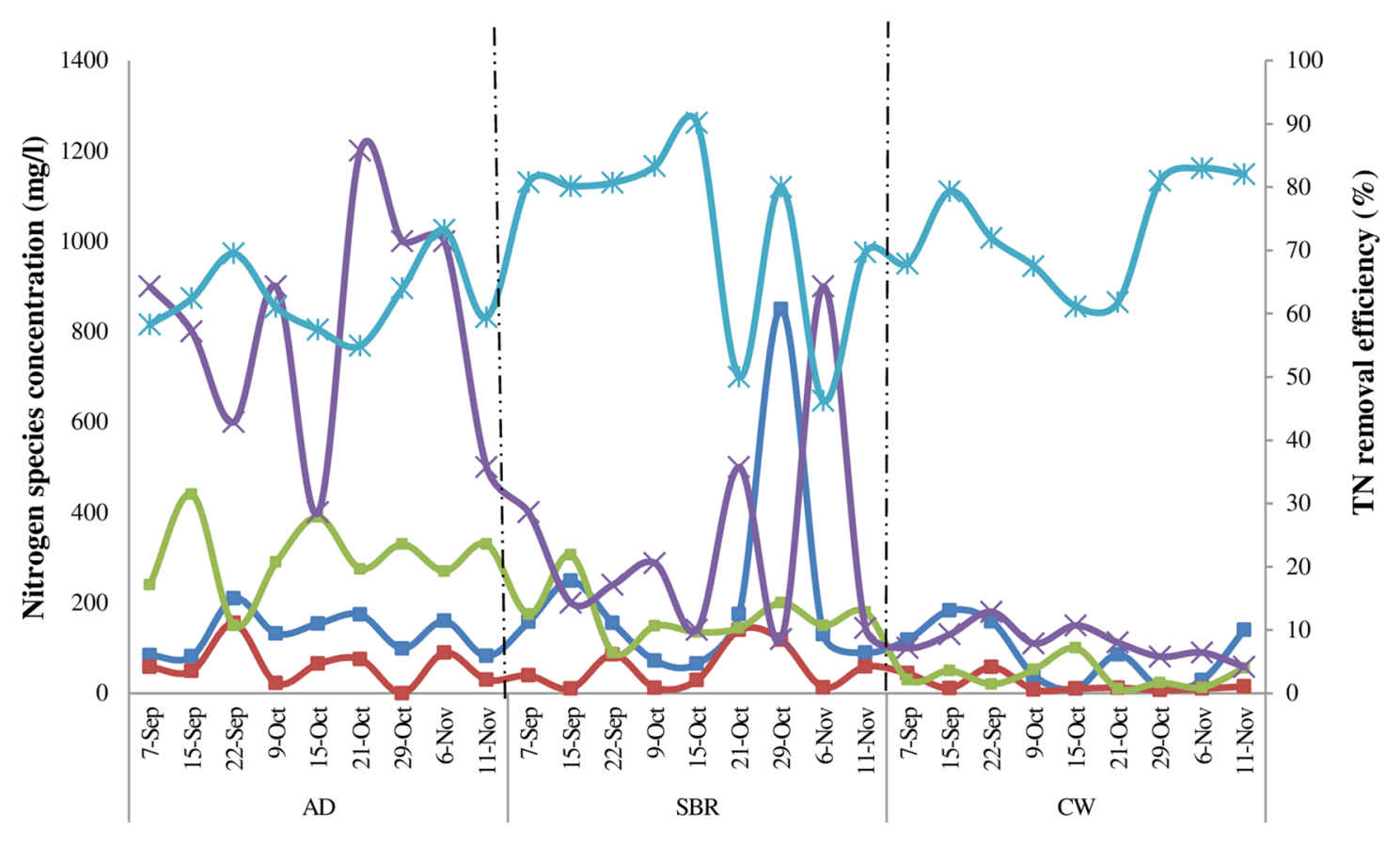

$=$ Influent ammonium-N $=$ Effluent ammonium-N $=$ Effluent nitrate- $\cong$ Effluent nitrite-N $\approx-$ TN removal efficiency

Fig. 7 Influent and effluent concentrations of nitrogen species and TN removal efficiency at each unit operation

average concentrations in the effluent of $39.3 \mathrm{mg} / \mathrm{l}\left(\mathrm{NO}_{3}-\mathrm{N}\right)$, $112.3 \mathrm{mg} / \mathrm{l}\left(\mathrm{NO}_{2}-\mathrm{N}\right)$, and $19.5 \mathrm{mg} / \mathrm{l}\left(\mathrm{NH}_{4}-\mathrm{N}\right)($ Table 3$)$. The removal of $\mathrm{NO}_{3}-\mathrm{N}, \mathrm{NO}_{2}-\mathrm{N}$, and $\mathrm{NH}_{4}-\mathrm{N}$ increased progressively in unit operations of anaerobic digestion and the aerobic reactor to achieve immense removal in the constructed wetland system.

The subsurface constructed wetlands showed significantly better removal efficiency $(p<0.05)$ for $\mathrm{NO}_{3}-\mathrm{N}$ than for the two other unit operations. The removal efficiency was higher for $\mathrm{NO}_{2}-\mathrm{N}$ and $\mathrm{NH}_{4}-\mathrm{N}$, but the difference was not statistically significant at $p<0.05$. The ASBR showed significantly higher removal efficiency (at $p<0.05$ ) for total nitrogen than the other operations. These results indicate that continuous biological treatment systems are the most efficient mode of operation for the removal of nitrogen species.

Similar results obtained by Desta et al. (2014) found that the integrated biological treatment system removed $87 \%$ of $\mathrm{NO}_{3}-\mathrm{N}, 99 \%$ of $\mathrm{NO}_{2}-\mathrm{N}$, and $85 \%$ of $\mathrm{NH}_{3}-\mathrm{N}$. The removal efficiency for total nitrogen was $74 \%$, and its concentration in the effluent $(62.7 \mathrm{mg} / \mathrm{l})$ was above the discharge limit. Alemu et al. (2016) reported an average removal efficiency of $90 \%$ for $\mathrm{TN}, 97 \%$ for $\mathrm{NH}_{3}-\mathrm{N}$, and $96 \%$ for $\mathrm{NO}_{3}-\mathrm{N}$.

The concentrations of nitrate and nitrite in the effluent of AD were $301.7 \mathrm{mg} / \mathrm{l}$ and $811.1 \mathrm{mg} / \mathrm{l}$ (Table 3), respectively, with removal efficiencies of $49 \%$ for $\mathrm{NO}_{3}{ }^{-}-\mathrm{N}$ and $52 \%$ for
$\mathrm{NO}_{2}{ }^{-}-\mathrm{N}$. Since nitrate reduction is always accompanied by nitrite production, nitrate removal efficiency is given in terms of oxidized nitrogen $\left(\mathrm{NO}_{X}-\mathrm{N}\right)\left(\mathrm{NO}_{3}-\mathrm{N}+\mathrm{NO}_{3}-\mathrm{N}\right)$. The maximum oxidized nitrogen $\left(\mathrm{NO}_{X}-\mathrm{N}\right)$ removed from $\mathrm{AD}$ was $67 \%$, leaving a concentration of $830 \mathrm{mg} / \mathrm{L} \mathrm{NO}_{X}-\mathrm{N}$ in the effluent (Fig. 8). The conversion of the non-aeration period to the aeration period in aerobic SBR apparently improved the $\mathrm{NO}_{X}-\mathrm{N}$ removal efficiency to $76 \%$ with a lower $320 \mathrm{mg} / \mathrm{l}$ oxidized nitrogen concentration in the effluent. Further conversion to the aeration period in the $\mathrm{CW}$ saw the $\mathrm{NO}_{X}-\mathrm{N}$ removal efficiency improve progressively to $96 \%$ with $200 \mathrm{mg} / \mathrm{l}$ concentration of $\mathrm{NO}_{X}-\mathrm{N}$ in the effluent.

The $\mathrm{COD} / \mathrm{NO}_{3}-\mathrm{N}$ ratio of wastewater determines the biological processes most suitable for removing nitrogen. The $\mathrm{COD} / \mathrm{NO}_{3}-\mathrm{N}$ ratio in the influent was 10.6 and in the effluent 4.9 (Fig. 8). According to Campos et al. (2010), nitrogen will be removed by assimilation and nitrification and denitrification when the $\mathrm{COD} / \mathrm{NO}_{3}-\mathrm{N}$ ratio ranges from 5 to 20 . When the $\mathrm{COD} / \mathrm{NO}_{3}-\mathrm{N}$ ratio is less than 5 , nitrogen removal, as observed in our study, will be by partial nitrification-denitrification or partial nitrification anammox (anaerobic ammonium oxidation). In this process, ammonia in the presence of nitrite as the electron acceptor oxidizes to nitrogen gas under anoxic conditions. Therefore, the available organic material in the influent was enough for efficient nitrogen removal in each biological unit operation. 


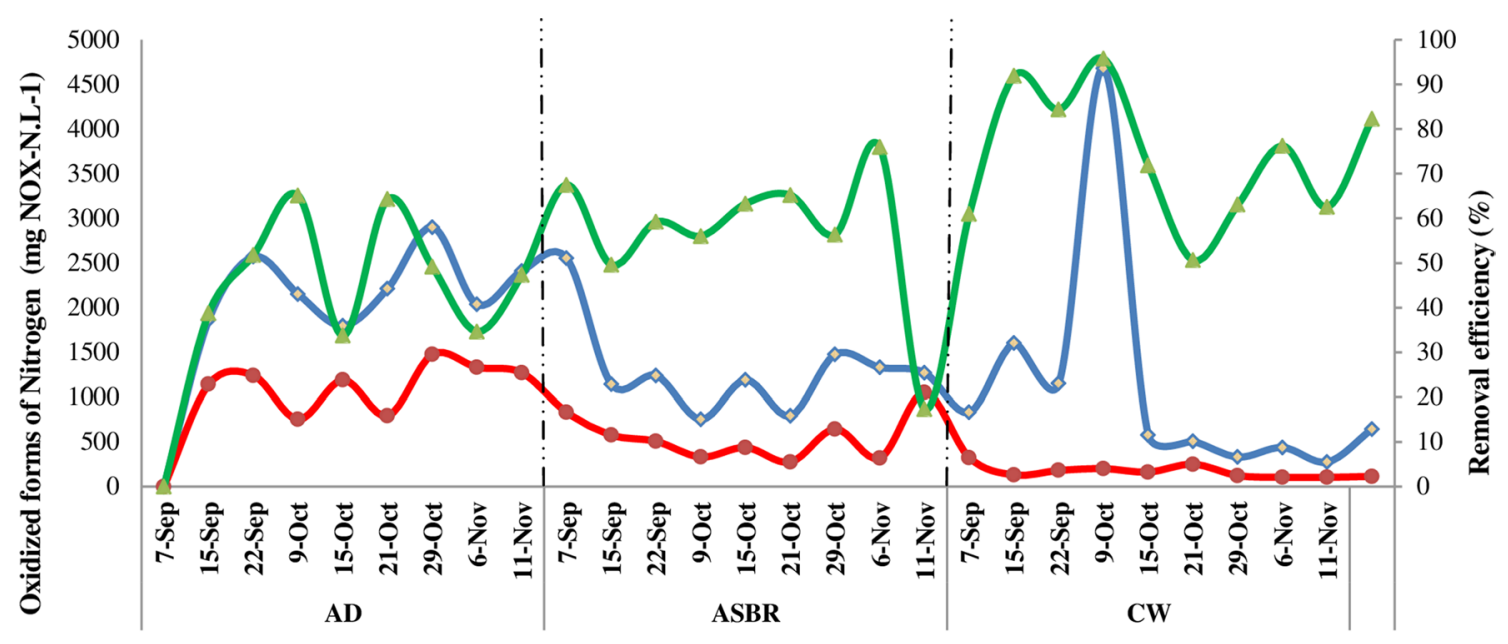

$\leadsto$ Influent $\multimap$ Effluent $\multimap$ Removal efficiency $(\%)$

Fig. 8 Variation in $\mathrm{NO}_{X}-\mathrm{N}$ removal efficiency (in percent) and average $\mathrm{NO}_{X}-\mathrm{N}$ concentration in the influent and effluent of each unit

\section{Conclusion}

This study found considerable amounts of solids and high levels of $\mathrm{BOD}_{5}, \mathrm{COD}$, and nitrogenous compounds in tannery wastewater, and the effluent showed a high $\mathrm{BOD}_{5} /$ COD ratio explained by the presence of organic matter in the wastewater. Optimum $\mathrm{pH}$ and temperatures values exhibited in the unit operations suggest that the integrated biological system in the current study is suitable for rapid growth of bacteria responsible for nitrification and denitrification.

Higher removal efficiency for TSS, turbidity, $\mathrm{BOD}_{5}$, $\mathrm{COD}, \mathrm{NO}_{3}-\mathrm{N}, \mathrm{NO}_{2}-\mathrm{N}, \mathrm{NH}_{4}-\mathrm{N}, \mathrm{S}^{2-}$, and $\mathrm{PO}_{4}{ }^{3-}$ were observed in $\mathrm{CW}$ than in $\mathrm{AD}$ and $\mathrm{ASBR}$, whereas aerobic SBR showed higher removal efficiency for TDS and TN and anaerobic digesters achieved the highest removal of sulfate $\left(\mathrm{SO}_{4}^{2}\right)$. The removal of $\mathrm{NO}_{3}-\mathrm{N}, \mathrm{NO}_{2}-\mathrm{N}$, and $\mathrm{NH}_{4}-\mathrm{N}$ increased progressively in the unit operations of anaerobic digestion and aerobic reactor to achieve a high level of removal in the constructed wetland system. Hence, the application of a combined anaerobic/aerobic system connected with the CWs process achieved higher nitrogen removal efficiency than the use of a singular anaerobic and aerobic process.

The final treated effluent meets provisional discharge limits of the tannery effluent set by the Ethiopian Environmental Protection Authority except for the nitrate level, which might be due to insufficient carbon and external organic sources in the wastewater. These finding suggest that supplementing the carbon source for the effluent may achieve high nitrogen removal in the HSSFCW. This suggests that the combined anaerobic-aerobic and constructed wetland system may be used for the treatment of highstrength agro-industrial wastewater. Proper wastewater treatment and the application of waste-to-energy principles should be promoted in planning and operating tanneries for sustainable economic, environmental, and social benefits.

Acknowledgements We would like to thank Modjo Tannery Share Company for providing all the vital information and for unreserved support during sample collection and the Environmental Science Research Laboratory of Addis Ababa University for giving permission to use the laboratory facilities. We also acknowledge the Ethiopian Institute of Water Resources, Addis Ababa University, for financial support.

Funding This work was supported by US Agency for International Development (USAID) under the USAID/HED funded grants in the Africa-US Higher Education Initiative-HED 052-9740-ETH-11-01.

\section{Compliance with ethical standards}

Conflict of interest The authors declare that they have no conflict of interest.

Open Access This article is distributed under the terms of the Creative Commons Attribution 4.0 International License (http://creativeco mmons.org/licenses/by/4.0/), which permits unrestricted use, distribution, and reproduction in any medium, provided you give appropriate credit to the original author(s) and the source, provide a link to the Creative Commons license, and indicate if changes were made. 


\section{References}

Alemu T, Leta S (2015) Evaluation of selected wetland plants for removal of chromium from tannery wastewater in constructed wetlands, Ethiopia. Afr J Environ Sci Technol 9(5):420-427. https ://doi.org/10.5897/AJEST2014.1793

Alemu T, Lemma E, Mekonnen A, Leta S (2016) Performance of pilot scale anaerobic-sbr system integrated with constructed wetlands for the treatment of tannery wastewater. Environ Process 3(4):815-827. https://doi.org/10.1007/s40710-016-0171-1

APHA, AWWA, WEF (1998) Standard methods for the examination of water and wastewater, 20th edn. American Public Health Association, American Water Works Association, Water Environment Federation, Washington, DC

Barnes D, Bliss P (1983) Biological control of nitrogen in wastewater treatment, 2nd edn. E. \& F. N. Spon, London

Calheiros CSC, Quitério PVB, Silva G, Crispim LFC, Brix H, Moura SC, Castro PML (2012) Use of constructed wetland systems with Arundo and Sarcocornia for polishing high salinity tannery wastewater. J Environ Manag 95(1):66-71. https://doi.org/10.1016/j. jenvman.2011.10.003

Campos JL, Vázquez-Padín JR, Figueroa M, Fajardo C, Méndez A, Mosquera-Corral R, Méndez R (2010) Novel biological nitrogenremoval processes: applications and perspectives. In: Canton KW (ed) Fluid waste disposal. Nova Science Publishers, New York, pp 155-180

de Sousa JT, Santos KD, Henrique IN, Brasil DP, Santos EC (2008) Anaerobic digestion and the denitrification in UASB reactor. J Urb Environ Eng 2(2):63-67. https://doi.org/10.4090/juee.2008. v2n2.063067

Desta AF, Assefa F, Leta S, Stomeo F, Wamalwa M, Njahira M, Appolinaire D (2014) Microbial community structure and diversity in an integrated system of anaerobic-aerobic reactors and a constructed wetland for the treatment of tannery wastewater in Modjo, Ethiopia. PLoS One 9(12):1-22. https://doi.org/10.1371/ journal.pone. 0115576

Durai G, Rajasimman M (2011) Biological treatment of tannery wastewater: a review. J Environ Sci Technol 4(1):1-17

Durai G, Rajamohan N, Karthikeyan C, Rajasimman M (2010) Kinetics studies on biological treatment of tannery wastewater using mixed culture. Int J Chem Mol Nucl Mater Metall Eng 4(1):118-122

EEPA (2003) Standards for industrial pollution control in Ethiopia, part three: standards for specified inductrial sectors. Federal Environmental Protection Authority of Ethiopia. ESIS Project - US/ ETH/99/068/ETHIOPIA, EPA/UNIDO, Addis Ababa

Fan J, Zhang B, Zhang J, Ngo HH, Guo W, Liu F (2013) Intermittent aeration strategy to enhance organics and nitrogen removal in subsurface flow constructed wetlands. Biores Technol 141:117-122

Faouzi M, Merzouki M, Benlemlih M (2013) Contribution to optimize the biological treatment of synthetic tannery effluent by the sequencing batch reactor. J Mater Environ Sci 4(4):532-541

Ganesh R, Sousbie P, Torrijos M, Bernet N, Ramanujam RA (2014) Nitrification and denitrification characteristics in a sequencing batch reactor treating tannery wastewater. Clean Technol Environ Pol 17(3):735-745. https://doi.org/10.1007/s10098-014-0829-1

Gerardi MH (2002) Nitrification and denitrification in the activated sludge process. Wastewater microbiology series. Wiley, New York, pp 1-193

Goswami S, Mazumder D (2014) Scope of biological treatment for composite tannery wastewater. Int J Environ Sci 5(3):607-622. https://doi.org/10.6088/ijes.2014050100054

Hach Company (2004) DR/2400 Spectrophotometer procedures manual. Loveland, USA

Kadlec R, Wallace S (2009) Treatment wetlands, 2nd edn. Taylor and Francis Group, Boca Raton
Kongjao S, Damronglerd S, Hunsom M (2008) Simultaneous removal of organic and inorganic pollutants in tannery wastewater using electro coagulation technique. Korean J Chem Eng 25:703-709

Lee CG, Fletcher TD, Sun G (2009) Nitrogen removal in constructed wetland systems. Eng Life Sci 9(1):11-22. https://doi. org/10.1002/elsc.200800049

Lefebvre O, Vasudevan N, Torrijos M, Thanasekaran K, Moletta R (2006) Anaerobic digestion of tannery soak liquor with an aerobic post-treatment. Water Res 40(7):1492-1500. https://doi. org/10.1016/j.watres.2006.02.004

Paredes D, Kuschk P, Mbwette TSA, Stange F, Müller RA, Köser H (2007) New aspects of microbial nitrogen transformations in the context of wastewater treatment: a review. Eng Life Sci 7(1):13 25. https://doi.org/10.1002/elsc.200620170

Pire-Sierra MC, Cegarra-Badell DD, Carrasquero-Ferrer SJ, AnguloCubillan NE, Díaz-Montiel AR (2016) Nitrogen and COD removal from tannery wastewater using biological and physicochemical treatments. Revista Facultad de Ingeniería 80:63-73. https://doi.org/10.17533/udea.redin.n80a08

Redmond E (2012) Nitrogen removal from wastewater by an aerated subsurface flow constructed wetland. University of Iowa, Iowa

Reemtsma T, Jekel M (1997) Dissolved organics in tannery wastewaters and their alteration by a combined anaerobic and aerobic treatment. Water Res 31:1035-1046

Seyoum L, Fassil A, Dalhammar G (2003) Characterization of tannery wastewater and assessment of downstream pollution profiles along Modjo River in Ethiopia. Ethiop J Biol Sci 2(2):157-168

Seyoum L, Fassil A, Gumaelius L (2004a) Biological nitrogen and organic matter removal from tannery wastewater in pilot plant operations in Ethiopia. Appl Microbiol Biotechnol 66(3):333339. https://doi.org/10.1007/s00253-004-1715-2

Seyoum L, Gumaelius L, Fassil A, Dalhammar G (2004b) Identification of efficient denitrifying bacteria from tannery wastewater in Ethiopia and a study of effects of chromium III and sulphide on their denitrification rate. World J Microbiol Biotechnol 20(4):405-411

Tadesse I, Green FB, Puhakka JA (2004) Seasonal and diurnal variations of temperature, $\mathrm{pH}$ and dissolved oxygen in advanced integrated wastewater pond system treating tannery effluent. Water Res 38:645-654. https://doi.org/10.1016/j.watres.2003.10.006

Tehobanoglous G, Burton FL, Stensel HD (2003) Wastewater engineering: treatment and reuse, 4th edn. McGraw-Hill Companies Inc., New York

UNIDO (2000) Definitions and environmental impact. In: Pollutants in tannery effluents. United Nations Industrial Development Organization, pp 1-14

UNIDO (2011) Introduction to treatment of tannery effluents: What every tanner should know about effluent treatment. United Nations Industrial Development Organization, Vienna

Vanatta LE, Slingsby RW (2003) Environmental regulations and technology control of pathogens and vector attraction in sewage sludge control of pathogens and vector attraction. Environ Prot. https:// doi.org/10.1016/S0015-1882(99)80035-4

Wu G, Zheng D, Xing L (2014) Nitritation and $\mathrm{N}_{2} \mathrm{O}$ emission in a denitrification and nitrification two-sludge system treating high ammonium containing wastewater. Water 6(10):2978-2992. https ://doi.org/10.3390/w6102978

Publisher's Note Springer Nature remains neutral with regard to jurisdictional claims in published maps and institutional affiliations. 